\title{
Ciudades balnearias latinoamericanas. Una aproximación a los estudios culturales urbanos a través de los casos de Mar del Plata, Punta del Este y Río de Janeiro
}

\author{
Latin-American seaside cities.
}

\author{
An approach to urban cultural studies through the cases \\ of Mar del Plata, Punta del Este and Rio de Janeiro
}

\section{Daniel Cajarville*}

* Licenciado en Sociología (Universidad de la República, Uruguay). Magíster en Antropología (Universidad Federal Fluminense, Brasil). Doctorando en Integración de América Latina (Universidad de San Pablo, Brasil). Integrante del Instituto María Díaz de Guerra (Maldonado, Uruguay). Interesado en las transformaciones materiales y simbólicas del litoral este uruguayo en tiempos de movilidades turísticas y nuevas migraciones.

$\triangle$ daniel.cajarville@gmail.com https://orcid.org/0000-00033198-6100

\section{RECIBID0: 16.2 .2021}

\section{Resumen}

En diálogo con los estudios culturales urbanos, este artículo propone indagar teóricamente sobre la ciudad latinoamericana, entendida como ámbito vehiculizador de ideas y de transformaciones en el continente, a partir de ciudades balnearias como Mar del Plata, Punta del Este y Río de Janeiro. En tal sentido, se propone que las sociabilidades a las que estas ciudades dan curso inciden en la historia de la región y promueven, hacia dentro y fuera de fronteras, símbolos, imágenes, narrativas y experiencias tanto nacionales como regionales.

Palabras clave: estudios culturales, zona urbana, turismo, América Latina.

\section{Abstract}

In dialogue with urban cultural studies, this article proposes to reflect theoretically on the Latin American city, regarded as a vehicle for ideas and transformations in the continent, from seaside cities such as Mar del Plata, Punta del Este and Rio de Janeiro. In this sense, it is proposed that the socializing experiences these resorts enable affect the history of the region and. 
promote, inside and outside borders, symbols, images, narratives and experiences, both national and regional.

Key words: cultural studies, urban areas, tourism, Latin America.

\section{Introducción}

Este trabajo indaga sobre la ciudad, entendida como protagonista de la historia de América Latina en su manifestación balnearia y más allá. La ciudad latinoamericana en cuanto categoría puede ser leída como «arena cultural» (Morse, 2005), un ámbito de intercambio y disputa entre experimentaciones culturales e ideas; también puede ser interpretada como «ciudad letrada» (Rama, 1998), considerando a la administración del poder y el control de la palabra (o de los signos) como aliados para avanzar en el territorio. La ciudad latinoamericana emerge como centro de la vida cultural moderna en América Latina; «las ciudades y las ideas», tal como son abordadas por Romero (2004), en estrecha asociación echan a andar la región. En esa dirección, podría afirmarse que «la ciudad y sus representaciones se producen mutuamente» (Gorelik, 2004, p. 2), y la representación no es solamente un medio para decodificar la ciudad, sino también para transformarla. En diálogo con reflexiones de los autores antes citados, así como de varios otros, este artículo discute sobre la ciudad balnearia latinoamericana.

La existencia de espacios urbanos localizados en entornos paisajísticos naturales y pensados para personas que, en su mayoría, los habitan por períodos exiguos fue una novedad que se afianzó en la Europa del siglo XIX (Corbin, 1989). Estas urbanizaciones, denominadas estaciones balnearias, estaciones de baños o lisa y llanamente balnearios, al final de aquel siglo serían reproducidas en las costas y serranías de América del Sur (Hernández, 2009). Entre finales del siglo XIX y principios del siglo XX, surgieron en las afueras de Montevideo zonas balnearias como Carrasco, mientras Río de Janeiro atravesaba un proceso análogo con las playas de Copacabana (Da Cunha y Campodónico, 2012; O’Donnell, 2013). Una ciudad como Mar del Plata, lejos de grandes urbes, inició su consolidación en igual período atrayendo a los metropolitanos habitantes de Buenos Aires. Otras urbanizaciones costeras como Viña del Mar o Punta del Este, a corta distancia de capitales nacionales como Santiago o Montevideo, se tornaron a lo largo del siglo $\mathrm{XX}$ en pujantes ciudades que atrajeron visitantes de dentro y fuera de las fronteras nacionales.

Esos territorios dieron espacio físico a actividades ociosas, terapéuticas y hedonistas, a la vez que también espacio material y simbólico de encuentro para muchos de quienes han pensado y tomado decisiones sobre los destinos de América Latina. Ello invita a dialogar con cuanto propone pensar Simmel (1986, p. 644) al señalar: 
No son las formas de la proximidad o distancia espaciales las que producen los fenómenos de la vecindad o extranjería [...]. Lo que tiene importancia social no es el espacio, sino el eslabonamiento y conexión de las partes del espacio, producidos por factores espirituales.

Los balnearios emergen como espacios que permiten tal aproximación al encontrar a quienes se identifican como iguales sin mayores obstáculos. Las relaciones entabladas en espacios costeros balnearios remiten a interacciones con la potencialidad de trascender los trazos de ocio y banalidad que les son adjudicados. Encontramos allí puntos de impulso modernizador, ¿tal vez?,1 además de escenarios para la promoción y el encuentro de proyectos e ideas a través de la sociabilidad balnearia. Lugares de excepción atravesados por osadas propuestas urbanísticas y arquitectónicas, así como enclaves emisarios de imágenes nacionales y regionales.

\section{La ciudad latinoamericana y las ideas}

La ciudad latinoamericana representa una construcción cultural, de acuerdo a Gorelik (2005), en cuanto categoría del pensamiento social que, entre las similitudes y diferencias de cada una de sus manifestaciones, puede ser pensada en sí misma. Emerge como idea guía, entre coyunturas, momentos y regiones específicas de otra idea guía, América Latina; posibilita, en ese marco, reflexiones múltiples y valiosas. En el artículo La ciudad artificial, Richard Morse (1957, p. 285) sostiene que en la Europa medieval «la ciudad constituía un punto natural de cristalización para las regiones inmediatas y las arterias comerciales de gran alcance», según retoma de los trabajos de Henri Pirenne sobre el desarrollo «centrípeto» de la ciudad europea. Ante esa ciudad «natural», la ciudad latinoamericana es definida en contraste como «artificial» y de desarrollo «centrífugo», puesto que «representaba la intrusión de una burocracia oficial y metropolitana, bajo su doble aspecto imperial y eclesiástico, en un vasto continente sin colonizar» (p. 286). La ciudad colonial de los ibéricos en América «se convirtió en un simple punto de partida, un trampolín en el cual saltaban las personas más emprendedoras y, con frecuencia, más privilegiadas» (Morse, 1957). Ello no siempre sería así.

Las ciudades latinoamericanas anteriores a la colonia - Cuzco y Tenochtitlán son ejemplos - surgieron como ciudades naturales fruto de la necesidad y no meramente de la planificación, urbes de formación heterónoma en lugar de autónoma. Luego del culturación (Rama, 2007). 
arribo ibérico, proliferaron urbanizaciones usualmente fortificadas y yuxtapuestas al territorio americano, que extendieron sobre sus territorios linderos nuevas formas organizativas, impuestas por la metrópolis. «Aunque aisladas dentro de la inmensidad espacial y cultural, ajena y hostil, a las ciudades competía dominar y civilizar su contorno, lo que se llamó primero "evangelizar" y después "educar"», señala Rama (1998, p. 27). ${ }^{2}$ Para Romero (2004), la vida urbana era escasa antes del desembarco de España y Portugal, y luego se formó una constelación de ciudades conocidas que legitimaban la propiedad de vastos territorios desconocidos, tomados incluso como «vacíos» en un discurso de dominación que justificó atribuciones colonizadoras. Las masivas corrientes migratorias del campo a la ciudad, a partir de los años treinta, serían un hito que revertiría en gran medida las tendencias antes descritas (Romero, 2004). Respecto a décadas posteriores, Richard Morse señala: «[...] pela primeira vez desde a Conquista européia a cidade não representa um bastião intruso no domínio rural, nem constitui um centro de controle sobre si mesmo: a Nação invadiu a cidade» (Morse citado por Gorelik, 2005, p. 128).

Desde la colonia, luego del ciclo de la independencia y adentrándonos en el siglo $\mathrm{XX}$, la ciudad latinoamericana abraza la tarea de inducir la modernidad occidental en la región. Morse (2005) encuentra espacios urbanos que componen «arenas culturales» en el continente, en la periferia de la modernidad, aunque sin dejar de estar en ella. Si París y Londres forman el centro de la modernidad, una «primera periferia» estaría compuesta por San Petersburgo y Viena; enseguida Buenos Aires y Río de Janeiro adquieren el rol cultural de una «segunda periferia», propone el autor. América Latina coexiste con relación a un centro ante el cual dialoga e interviene, sin sumirse en una mera espera pasiva y silenciosa para salir de un endilgado atraso. Morse «interpreta a las urbes como crisoles para el cambio en la era moderna [...]» $(2005$, p. 1.) y propone «la existencia en América Latina tanto de predisposiciones como de resistencias capaces de rechazar, avivar o metamorfosear la inspiración modernista» (p. 2). ${ }^{3}$ El historiador sugiere que «una sociedad reacia puede producir logros de vanguardia» (p. 5). Las distantes ciudades latinoamericanas fueron tierra fértil para «mensajes proféticos»y «sutiles parábolas» como las de Machado de Assis.

Las instituciones urbanas, a través de sus representantes administrativos e intelectuales, intervinieron sobre su territorio circundante en los primeros tiempos de la colonia, instalando un nuevo orden (Rama, 1998, p.27). Ese proceso se diferenció de aquel transitado por las ciudades orgánicas europeas y precolombinas, las cuales se formaron partir de su entorno cercano. De esa forma remite Rama (1998) a la noción de ciudades naturales.

3 De acuerdo con Morse (2005), mientras las ciudades europeas centrales (París y Londres) se proponen como destino universal, en el marco de un proceso de racionalización/modernización, un cambio de sensibilidad hacia lo particular atraviesa arenas culturales fuera de esas grandes urbes. 
Entre la «ciudad patricia» y la «ciudad burguesa» del siglo XIX, abordadas por Romero (2004) en su ensayo América Latina: las ciudades y las ideas, se encuentra que lo rural y caudillesco, en apogeo luego de las independencias, confluye con una creciente valoración de lo europeo como modelo. Entre su hinterland y las referencias de Londres y París, se abrió paso la ciudad latinoamericana en el siglo XIX, acompañando un eterno dualismo entre campo y ciudad. Morse insiste en que «no puede afirmarse que la periferia refleje el centro» (2005, p. 11), al ser la ciudad un medio fértil para la gestación de producciones singulares. Tras dejar atrás su pasado colonial, enfrentando una creciente tensión en su relación con ruralidades circundantes, las ciudades se muestran dispuestas a emular nuevos moldes provenientes del hemisferio norte: las parisinas avenidas de Haussmann, por un lado; las estancias balnearias de Biarritz, Lido, Ostende y más adelante Palm Beach, por otro. Esas tendencias urbanísticas serán reversionadas con mayor o menor grado de originalidad desde las especificidades locales. La «ciudad masificada» (Romero, 2004) de la segunda mitad del siglo XX, entre una incipiente o avanzada industrialización y una avasallante densificación urbana, encuentra a más personas y diferentes entre sí, heterogeneizando los intercambios y dinámicas urbanas. Esto sin necesariamente esperar de ellas una impersonalidad y actitud blasé al estilo de las metrópolis del norte.

A partir de la década de 1990, se dio «una creciente focalización en otras geografías y conceptos, en tanto el destino de cada ciudad en América Latina comenzó a ser abordado en relación a actores que trascendían la región y estaban crecientemente desnacionalizados» (Jajamovich et al., 2016, p. 5). Las ciudades latinoamericanas buscaron ser parte de un archipiélago de «ciudades globales». Muchas de ellas integran circuitos internacionales, aunque, «como se sabe, las ciudades latinoamericanas nacieron "mundializadas" y lo han seguido estando desde su mismo origen» (Gorelik, 2007, p. 39). Insertarse en transnacionales flujos de capitales no es sencillo, aunque provoca expectativas que mueven un «deseo de globalización» que, plantea Gorelik (2007), refuerza fragmentaciones urbanas históricas. Un prototípico ejemplo de ello se observa en las remociones de población de los alrededores de la Barra Olímpica, ante el avance de ambiciosos proyectos inmobiliarios (O’Donnell et al., 2020); así como en el proyecto Porto Maravilha, que transforma los márgenes de la bahía de Guanabara al tiempo que estiliza el paisaje urbano y promueve la radicación de empresas, mientras antiguos pobladores se ven obligados a alejarse del centro carioca (Sarue, 2016).

Un «planeamiento estratégico» (Urry, 2016) surge como manifestación de tales expectativas de reconversión urbana, promoviendo la revalorización de áreas urbanas perimidas para atraer ambiciosos capitales financieros e inmobiliarios. Asimismo, también en las últimas décadas, «tornar-se um destino turístico é parte do processo reflexivo por meio do qual sociedades e lugares se "inserem" na ordem global» (p. 144). 


\section{Las ciudades balnearias}

Entre ideas «importadas» y la coincidencia de estas con las particularidades de la realidad latinoamericana, los espacios balnearios surgen como entornos paisajísticos con trazos urbanos «pero no tanto». Entre finales del siglo XIX y comienzos del siglo XX, los emergentes círculos de una nueva burguesía latinoamericana procuraron ámbitos exclusivos para «ver y ser vistos» entre iguales, tal como señala José Luis Romero (2004, pp. 321-322). La misma percepción revela el antropólogo brasileño Thales de Azevedo (2016), algunos años después, cuando escribe sobre la «cultura da praia» que vivenció entre las costas de Bahía y Montevideo, destacando los trazos de una sociabilidad habitual a muchas zonas de veraneo. El turismo arriba en aquel entonces a América Latina trayendo consigo «un complejo proceso de transformaciones sociales y económicas que implicó la difusión de nuevas prácticas, discursos y representaciones» (Pastoriza y Campodónico, 2020).

La ciudad balnearia se sitúa en ese contexto como enclave de relaciones de poder, a modo de espacio de intercambios culturales y nudo de encuentros que posibilitan la sociabilidad de quienes tienen acceso. En ese marco, la diseminación de nuevas ideas y prácticas ha compuesto el cotidiano veraniego de ciudades balnearias como Mar del Plata o Punta del Este. Ello también se ve impulsado en la ciudad capital, portuaria y comercial de Río de Janeiro, que a los fines de esta discusión adquiere también el calificativo de ciudad balnearia en términos de las dimensiones adquiridas por su franja costera sobre el Atlántico. En simultáneo, los espacios balnearios cobran proyección internacional, se tornan una fachada desde la que América Latina y principalmente las naciones que la componen se muestran.

Estas urbes litorales no solo acogen a las élites urbanas y otros visitantes. Sus seductores paisajes, agitadas agendas, fastuosas actividades incitan la atención de miradas e imaginaciones en remotas y cercanas regiones del globo. Se ve a través de ellas a las sociedades y culturas que evocan. Proyectan imágenes hacia fuera del territorio en que físicamente se sitúan, definiendo representaciones locales, nacionales y regionales.

\section{La sociabilidad balnearia}

El balneario es un ámbito eminente de sociabilidades, no necesariamente desinteresadas, ante lo cual adquiere trazos sui generis de arena cultural. Allí se reúnen élites y diversos sectores en ascenso, dinamizando los círculos en que se integran y reverberando ecos no solo desde sino también hacia las grandes ciudades. El consumo cultural allí presente resulta profuso en sus posibles expresiones, así como los intercambios espontáneos o mentados propios del encuentro entre visitantes asiduos u ocasionales, visitantes que se tornan residentes y residentes que nunca fueron visitantes. 
La exclusividad de aquel «ver y ser visto» fue disputada por la masificación de las ciudades balnearias. No obstante, esos territorios constantemente han reconfigurado formas excluyentes de ser usufructuados, que van desde desplazamientos a márgenes costeros vecinos - apreciables en el corrimiento de la playa Bristol a la playa Grande, en el caso de Mar del Plata- hasta la conformación de ámbitos privativos tales como clubes y hoteles de alta gama. Desde sus inicios, las vacaciones en la mencionada Perla del Atlántico fueron leídas como una forma de «ser alguien» (Pastoriza, 2011, p. 247), en un lugar que a principios del siglo XX fue caracterizado como «reducto aristocrático» (p. 125). A partir de finales de la década de 1920 y muy especialmente en las décadas de 1940-1950, la ciudad viraría hacia una «Mar del Plata para todos» (p. 231) que dejaba atrás aquel «exclusivismo» (p. 37) de un comienzo mediante iniciativas públicas para la ampliación del acceso a las vacaciones. Esta urbe balnearia argentina permanece como un reconocible punto de encuentro que, en los meses de verano, aglutina a quienes semanas antes se tropezaban en la gran ciudad.

Un espacio ocioso como lo es la costa, arenales improductivos convertidos en sitios de verano, emerge como suelos donde no solo se descansa o se invierte en el descanso de otros. Trochón (2017) señala a Punta del Este como un espacio de sociabilidad «exclusiva y excluyente» que permite tejer redes y fortalecer lazos. Multifacéticas se muestran las imágenes de ese destino a lo largo de su historia, atravesada por afanes de distinción, dado que "veranear en Punta del Este fue considerado símbolo de estatus social: solo mostrarse, deambular por sus calles, frecuentar sus playas y lugares de moda confería un prestigio particular» (p. 421). Ese «lugar distinguido y "chic"» (Trochón, 2017) ha sido protagonista del Uruguay turístico. Punta del Este fue pensada a imagen y semejanza de las estaciones balnearias europeas de principios de siglo, aunque en su historia también «mantuvo profundos lazos regionales en un doble sentido: por la movilidad intrarregional y en procesos de consolidación en sintonía» (Da Cunha y Campodónico, 2012, p. 364). Aun en la actualidad, la masificación de la actividad turística convive con el sello selecto de sus orígenes y desarrollo, lo que la torna una plaza singular de sociabilidades, principalmente entre argentinos, brasileños y uruguayos.

Río de Janeiro, en su franja costera sobre el océano Atlántico, acoge a la zona Sur de la ciudad, «puerta de acceso a todo un universo de status y prestigio» (O’Donnell, 2014, p. 3). La playa de Copacabana, por ejemplo, supo posicionarse como sinónimo de cosmopolitismo (Velho, 1999) a través de «sinais de distinção» que aún posee, a pesar del paso del tiempo y de las transformaciones del barrio (O’Donnell, 2014; Velho, 2004). Río de Janeiro se posiciona como un híbrido entre el balneario distante de la gran ciudad y esta última, y su zona Sur es un lugar de veraneo y de residencia permanente que aglomera a las élites brasileñas, a las capas medias cariocas en ascenso y a turistas de múltiples orígenes. Los paisajes locales y las experiencias que provocan, ante la ampliación 
de los flujos de residentes y visitantes, promovieron sucesivos desplazamientos a destinos linderos sobre el litoral fluminense. De Copacabana se avanzó a Ipanema, de Ipanema a Leblón, de Leblón a Barra da Tijuca, ${ }^{4}$ ante lo cual ha de argumentarse que «as elites sempre buscaram incessantemente novos locais turísticos para o seu lazer, cada vez mais exclusivos e inacessíveis, abandonando outros à medida que as "massas" de turistas iam chegando» (Castro, 1999, p. 86). Quienes se encuentran en la zona Sur remiten a una heterogeneidad cada vez mayor; la playa atrae a unos y otros, aunque las posibilidades de acceso resultan desiguales. La seducción de dicho entorno costero crea un ámbito de profusos intercambios, más aún para quienes cuentan con los medios para garantizar su permanencia y reclusión en costas cariocas.

Las zonas balnearias en cuestión sirvieron de punto de encuentro privilegiado para las elites y los sectores en ascenso de América del Sur, refugio del establishment social, político y empresarial; constituyeron espacios cosmopolitas para el intercambio de ideas y escenarios de experimentaciones. El balneario reúne a aquellos vinculados a la letra y al poder que la escritura media y que es mediado a la vez que legitimado por ella, quienes hacen a la «ciudad letrada» (Rama, 1994). Ellos se contraponen y/o complementan a los integrantes de una «ciudad real» (Rama, 1994), en gran medida ajena a la toma de decisiones, según sostiene el autor uruguayo. Lo hacen cada vez menos en sociedades latinoamericanas en las que el acceso a la información y los medios para influir sobre ella se ampliaron sustantivamente en el último siglo. Las letras se alejaron de sus funciones predominantemente cívicas y administrativas de antaño, sin perder ese papel, para ser objeto de una mayor pluralidad de fines (divulgación, recreación, etcétera) e incorporar una mayor amplitud de voces (más aún en tiempos de nuevas tecnologías).

La ciudad balnearia se sostiene desde hace más de cien años como reducto e influjo de quienes protagonizan las tramas narrativas de la economía, la política y la cultura latinoamericanas. Si bien la ciudad real amplía sus canales de comunicación, teniendo una voz de incidencia en redes sociales y otras vías propias de una sociedad habituada a heterogéneos flujos de interlocución, la letra allí aventaja, pero no pierde por completo preeminencia aquello que es dicho y escriturado por los letrados: al legislar, al realizar transacciones, al opinar o escribir sus ideas, ya sea en columnas de prensa o académicas investigaciones. La legitimación del poder permanece expectante del aval de la palabra, aun en tiempos de polifonías como los actuales. En el balneario convergen la «ciudad letrada» y la «ciudad real», de emprender al ejercicio de retomar ambas categorías en el contexto de ciudades globalizadas. Este prevalece como lugar excepcional que reúne y posibilita asociaciones entre quienes allí se ven y son vistos. A la vez, se

En Mar del Plata y Punta del Este se observan procesos análogos. Para el primer caso, la playa Bristol queda atrás frente a playa Grande y Punta Mogotes. Mientras que de la península puntaesteña se avanzó hacia La Barra, Manantiales y luego José Ignacio; también punta Ballena. No obstante, en cualquier caso, no se abandona por completo el alto valor y prestigio de los poblamientos anteriores. 
torna materia prima para imágenes y narrativas que vuelven a ese espacio en sí un lugar para ser visto, como se profundizará a continuación.

\section{Avanzar hacia el interior y el exterior}

Como ámbito propiciador de encuentros entre muchos de quienes tienen el poder para la toma de decisiones, la ciudad balnearia también se convierte en un escenario que atrae la atención nacional e internacional para mostrar a las naciones y la región en que se inscribe. Avanzar dentro y fuera del territorio se hace posible en tales entornos.

\section{Río: de la periferia carioca a la pasarela del Brasil}

Valéria Guimarães señala: «No início da década de 1920, quando o turismo brasileiro dava os seus primeiros passos acompanhando os esforços de entrada do país na modernidade, fazia todo o sentido investir no turismo receptivo internacional» (2013, p. 178). Con esas palabras la historiadora describe las primeras iniciativas gubernamentales para promover la práctica del turismo en territorio brasileño. La costa atlántica de la ciudad de Río de Janeiro, hasta entonces relegada a un segundo plano, adquirió relevancia para mostrar una ciudad latinoamericana privilegiada en la que se lucía una sociedad brasileña moderna y pujante. Previamente, Río se ofrecía al mundo enfatizando sus edificios, plazas y calles emuladoras de sus pares europeos, dejando sus playas como un aspecto irrelevante y anecdótico (Castro, 1999). Las razones para visitarla no diferían de aquellas que motivaban una visita a Buenos Aires o a Londres. De hecho, ambas ciudades aún no convocan por sus costas, también contiguas. El foco entonces para lo que hoy denominamos imagen de destino era mostrar una infraestructura a la altura de una gran urbe europea.

La celebración del centenario de la independencia, en 1922, seguida de la Exposición Universal, entre 1922 y 1923, así como la construcción de hoteles lujosos y la elaboración pionera de guías turísticas para aquella década, marcaron ese primer impulso (Castro, 1999). Las costas de Copacabana fueron entonces protagonistas. El personaje Zé Carioca lo dejaría claro en las animaciones de Disney en las que participó. Allí aparece deambulando por las veredas de la orla de Copacabana en vez de hacerlo por la céntrica rua do Ouvidor. Carmen Miranda también se mostraría en iguales escenarios y ambos ganarían fama internacional en el contexto de políticas de buena vecindad (Freire-Medeiros, 2005). Río de Janeiro como una ciudad con atractivos balnearios incorporó un sello playero para avanzar sobre territorios extranjeros, diseminando una brasilidad moderna y tropical que aún hoy el país muestra a través de nuevas producciones cinematográficas e incluso en importantes megaeventos, como los Juegos Olímpicos, organizados estratégicamente en las costas cariocas. 


\section{Mardel: emblema de un proyecto nacional de la Argentina}

Mar del Plata no intentó ocupar un rol menor; tanto es así que Juan Domingo Perón, al inaugurar el Festival Internacional de Cine de Mar del Plata, en 1954, afirmó que Mar del Plata era «la síntesis de la Argentina, porque si en la Argentina existe una ciudad tan opulenta, es porque la Argentina es opulenta» (Eltrece, 2010, 10:48), tal como indica Pastoriza en el documental citado. Mientras esas palabras irrumpían, estrellas del cine europeo y norteamericano se integraban a las figuras locales por algunos días, marcando un hito en el país y el Cono Sur (Pastoriza, 2011). El Festival, actualmente categoría A —al igual que aquellos organizados en Cannes, San Sebastián o Venecia, en los que se inspiró esta versión argentina-, permanece vigente. Aún promueve el cine nacional e internacional con imponencia, mostrando a su vez cuánto la Argentina hace y cuánto es capaz de organizar. La Ciudad Feliz, como también se la conoce, ha sido un destacado nicho teatral y escenario de decenas de películas junto con el balneario bonaerense Villa Gesell, y cumple una vez más su papel en la divulgación, la producción y la negociación en la industria cinematográfica nacional, además de pantalla del país dentro y fuera de fronteras.

Aunque «son variados los intentos de las diversas administraciones públicas por dotar al balneario de un sesgo internacional» (Pastoriza y Zuppa, 2004, p. 107) y ese objetivo persiste, la ciudad no logra atraer la atención de sus vecinas Río de Janeiro y Punta del Este. No obstante, el turismo social promovido por el peronismo a mediados del siglo XX significó una oportunidad material y simbólica de recurrir a Mar del Plata como mediadora de un proyecto nacional de igualación social (Pastoriza y Torre, 2019). Entre 1946 y 1955 se impulsaron las vacaciones remuneradas; se construyeron grandes complejos hoteleros sindicales o con intermediación sindical, como el gran Chapadmalal, entre otros que fueron fruto de la Fundación Eva Perón; hubo grandes campañas, como la célebre «Usted paga el pasaje; la provincia, el hospedaje», a lo que se sumaron facilidades para la construcción en altura y para la movilidad, según señalan Pastoriza y Pedetta (2009). En el proceso denominado «democratización del bienestar» (Pastoriza y Torre, 2002), la cuestión del acceso al ocio y al tiempo libre fue ocupando un espacio cada vez más destacado; se promovió el turismo como una vía para conocer el país y fortalecer la pertenencia y la identificación nacional. Asimismo, el derecho al veraneo en lugares como Mar del Plata fue emblema de la construcción de una imagen de nación en la que cada ciudadano podía «ser alguien» a través de la ampliación del acceso de lo que antes era un privilegio de pocos (Pastoriza y Torre, 2019).

En ese período histórico Mar del Plata fue un ícono simbólico para la construcción y la proyección de una imagen nacional. Su preeminencia trasciende fronteras adentro, sin dejar de persistir en el intento de mostrarse fuera de ellas con un imponente proyecto de urbe turística, lo cual, aunque en un considerable menor grado respecto de Río de Janeiro o Punta del Este, ha encontrado sus ecos. 


\section{Punta: foco de atención desde y para el Uruguay}

Punta del Este usualmente emerge como titular en la prensa regional e internacional dado su atractivo, el interés de quienes allí llegan y los acontecimientos que ambienta. En 1934 fue declarada zona «de interés nacional para el desarrollo del turismo», como apunta Díaz de Guerra (1988, p. 759) en referencia a los sucesivos e inusuales esfuerzos para el desarrollo del transporte, la hotelería y la gastronomía que la zona balnearia entonces convocó. Esta zona muestra cuánto Uruguay y la región son capaces de propiciar; las actividades e incluso las grandiosas construcciones que en la ciudad se levantan remiten a esfuerzos por cautivar con una imagen de modernidad costera. Sus mansiones representaron «la urbanización del inhóspito paisaje conformado por arenales, puntas rocosas y pinares», que adquiere «una buscada espectacularidad» (Campodónico y da Cunha, 2009, p. 618). A partir principalmente de la década de 1970 se sumó un creciente número de edificios en altura y se densificó a la vez el trazado urbano. Hoteles y casinos serían parte de la atracción, al igual que intermitentemente en Río de Janeiro y Mar del Plata. Es un escenario que atrae a los medios de comunicación, junto con los cuales se construye y eleva a un lugar deseado que ilustra sobre sí y su entorno con corresponsales nacionales y regionales presentes sostenidamente en los veranos desde el último cuarto de siglo XX (Trochón, 2017).

Gabriela Campodónico y Mariciana Zorzi (2019), al estudiar las memorias de pobladores puntaesteños, destacan a partir de la década del 1950 la «transición de una Punta del Este "de algodón a las lentejuelas", cuya imagen pasa a estar asociada a los referentes internacionales de la música y del cine» (p. 249), entre otras personalidades. Punta albergó a Vinicius de Moraes, quien allí residió algunos veranos y se presentaba periódicamente en el café La Fusa junto con María Creuza y Toquinho. La actriz Margarita Xirgú, el arquitecto Antonio Bonet, los escritores Pablo Neruda y Rafael Alberti eligieron ese mismo litoral urbano en momentos de exilio, pasaje que quedó registrado en sus producciones. Astor Piazzolla llegó incluso a componer la Suite Punta del Este en homenaje a su lugar de veraneo, a petición de la asociación local Centro de Artes y Letras. Allí también se organizó un Festival Internacional de Cine, aunque prontamente interrumpido en su continuidad, además de eventos artísticos de diverso género. Fue sede en 1961 de la conferencia que reunió a los primeros mandatarios de América para promover la Alianza para el Progreso. Son instancias que repercuten en el sello de «centralidad» que la ciudad tiene para el turismo uruguayo como «buque insignia» (Campodónico et al., 2014). El diseño urbano planificado, el esmero en su arquitectura, así como la permanencia de un atractivo asociado a las peculiaridades de sus visitantes, exponen una fachada extraordinaria de Uruguay y la región que acapara titulares, reportajes y stories. 


\section{Contracaras, contrastes y síntesis}

Río de Janeiro surge como una metonímica síntesis de valores y estilos de vida propios de Brasil, señala Bianca Freire-Medeiros (2005), y se transforma en el foco de narrativas literarias y fílmicas sobre la nación. La zona Sur carioca refleja un proyecto de «modernidad praiano-civilizatoria» (O’Donnell, 2014) en el que la naturaleza, la salud corporal, la comodidad urbana y el acceso a la cultura alcanzan multitudes. Igualmente, las rigurosas medidas de control de la circulación en las favelas durante la Cumbre de la Tierra Río + 92 adquirieron protagonismo en la prensa del momento y expusieron las contracaras de la belleza paisajística carioca (Castro, 1999).

En Punta del Este, el populoso asentamiento irregular Kennedy ocupa frecuentemente titulares de prensa al localizarse en una de las áreas más lujosas del balneario, sobre terrenos cedidos para la construcción de viviendas populares por el expresidente norteamericano cuyo apellido le da nombre, mientras las edificaciones planificadas jamás fueron concretadas. El lugar ha sido denominado «emblema del choque social» (Solomita, 2017). En Mar del Plata, «la gradual autoexclusión de los sectores de nivel socioeconómico alto, al ampliarse la participación de los sectores de nivel medio y al integrarse los sectores populares» (Mantero, 1997, p. 141), muestra claras señales de las distancias y rispideces locales y permite observar una insoslayable «cesión de la playa Bristol a los nuevos visitantes, a la par que los antiguos fueron ubicados en playa Grande» (Pastoriza y Zuppa, 2004, p. 102). La constitución física y simbólica de los espacios balnearios, entre una marcada segregación residencial y un ostensible cosmopolitismo, exhibe proezas y reciprocidades como las descritas a lo largo de este texto, sin estar exenta de contrastes como los recién referidos.

En un ida y vuelta que dialoga con los centros tomadores de decisión, los entornos balnearios más celebrados en la costa occidental del Atlántico sur sirven de bastiones a las sociedades que integran, repertorio de imágenes seleccionadas de cuánto aspiran a mostrar o interesa ver a diferentes mediadores culturales (medios de prensa, blogueros, otros). En las noticias que en el globo se cubren sobre esos escenarios modelados para el ocio, no faltan escenas de violencia, entre otros sucesos no planificados, aunque prevalece un halo de grandiosidad, belleza, fascinación y conquistas que favorecen la imagen de las naciones y regiones (Suramérica, Latinoamérica) de las que hacen eco. Al decir de Bignami (2002), no solo se muestran imágenes de cuanto allí se encuentra, sino que también allí se produce cuanto se quiere ver.

En ese sentido, a la ciudad balnearia podríamos atribuirle un carácter centrífugo, según la proposición de Pirenne reelaborada por Morse (1957), en cuanto vitrina de una sociedad que en ella se expone y desea hacerlo. Ya no solo se dirige hacia un territorio nacional que husmea sobre la vida de «ricos y famosos» que habitan el balneario, a los que tal vez puedan ocasionalmente sumarse como veraneantes; además, expone hacia fuera de fronteras sugestivos escenarios urbanos cuyas narrativas e imágenes idealizan 
la «opulencia», la «excepcionalidad», la «modernidad» de sus naciones y la región en el mundo. En tiempos de mayor circulación de información, bienes y personas, la ciudad balnearia se vuelve global al ser comunicada, y, de hecho, lo es cada vez más. Esta, desde sus inicios, fue una ciudad que trascendió ampliamente su perímetro urbano, dadas las repercusiones de su cotidiano.

El balneario suele surgir como una urbanización construida principalmente para la permanencia esporádica de habitantes de la gran ciudad. En algunos casos se convierte en parte de ella (Copacabana en Río de Janeiro, Carrasco en Montevideo), absorbido en su contigüidad; en otros se consolida como destino relativamente remoto, relegado a fines principalmente ociosos (Mar del Plata, Punta del Este). La sociabilidad a la cual se da cabida en Mardel, Punta o Río permite el encuentro de tomadores de decisión, así como la excepcionalidad y el atractivo de sus paisajes naturales y urbanos permiten exponer dentro y fuera de fronteras una imagen nacional de ánimo promisorio o, al menos, cautivante. En tal sentido, la ciudad balnearia, además de espacio de intercambios significativos y sociabilidad, avanza simbólicamente dentro y fuera del territorio nacional transmitiendo imágenes usualmente favorables a la nación y la región. En tiempos de movilidades e incesantes flujos informacionales, las principales ciudades balnearias latinoamericanas renuevan los avances modernizadores que dan continuidad a su historia. Sirven a los fines de ser parte del globo, con base en imágenes y significaciones proyectadas a tales fines, centrífugamente.

\section{Conclusión}

La ciudad latinoamericana fue forjada «a imagen y semejanza de una lejana burocracia metropolitana» (Gorelik, 2002, p. 43), avanzando sobre el territorio. Ante una voluntad planificada, artificialmente se levantaron las primeras ciudades coloniales (Morse, 2004). Aunque implantadas, lograron expresar fusiones y mezclas que les dieron autoridad (Morse, 2004). La arena pública de la ciudad produce sociedad, señala Gorelik (2002), en cuanto sede del poder económico, político y simbólico. El prestigio de las urbanizaciones costeras balnearias las vuelve fecundas en su legitimidad como medios para la experimentación, la discusión y la reflexión entre sus asiduos y esporádicos visitantes. Si pensamos la gran ciudad latinoamericana como un foco de avance, en cuanto ámbito de circulación y germinación de ideas que se extienden a territorios interioranos y extranjeros, los espacios balnearios en ella o en ciudades estrictamente balnearias adquieren un papel cultural y material de complicidad, continuidad o retroalimentación. El espacio balneario se hace eco de lazos y redes de influencia, así como atraviesa fronteras y proyecta narrativas e imágenes de la nación y la región, a las que nutre mientras también interioriza. 
Entre la emulación de modas del norte junto con creaciones y recreaciones desde el sur, las formas y rutinas balnearias no necesariamente invitan al enfrentamiento de ideas, aunque, entre lo desprevenido y lo planificado, tropiezan en sus calles quienes posiblemente se rencontrarán más adelante en ámbitos resolutivos. Siguiendo a Simmel (1986), el espacio en sí mismo poco puede decirnos frente a las relaciones que en él se entablan y los factores espirituales, o las relaciones de afinidad, allí establecidos. Los destinos balnearios, al menos los principales, nuclean a muchos de quienes disponen de los medios necesarios para tomar decisiones de peso o para contestarlas. Voces de resistencia pueden, o no, encontrarse también allí. El espacio balneario, según aquí se propone, surge como una extensión de la ciudad latinoamericana que en él se reúne; especialmente allí lo hacen sus sectores dominantes. A su vez, forma parte de ella sin dejar de ser ciudad en sí mismo, en un entorno de distensión que no por eso remite a la improductividad e inactividad. Las interrelaciones que se suscitan entre quienes se encuentran en su aire marítimo hablan de una espacialidad social común a la de la ciudad capital, ciudad puerto, ciudad comercial u otras. Aunque es una espacialidad también propia, una arena particular.

Los atractivos paisajísticos y la sociabilidad de las zonas balnearias conducen a identificarlas no solo como ámbitos de intercambio activo entre quienes allí se encuentran y se reconocen, sino también como espacios de circulación de ideas y experimentación sociocultural. A su vez, la atención que generan dirige dentro y fuera de fronteras tanto símbolos como elocuentes representaciones, realizaciones, singularidades de países y regiones a los que pertenecen. El signo de la configuración del espacio urbano y el signo de la lengua, sobre los cuales se extiende Rama (1994), entrecruzan espacios urbanos paisajísticos como los aquí abordados mediante un sinfín de materias periodísticas y producciones mediáticas que vehiculan narrativas e imágenes apelativas. En esas proyecciones saltan a la luz los contrastes sociales también asociados a estos territorios, aunque suelen prevalecer los rasgos de excepcionalidad paisajística y urbana, así como los trazos de una sociabilidad de alto estándar. Al balneario, a lo balneario, no puede negársele un papel sui generis en el avance de múltiples proyecciones simbólicas «centrífugas», con connotaciones próximas a las propuestas por Morse (1957). Tanto dentro como fuera de fronteras, selectivos trazos de atributos nacionales/regionales evocados en lo balneario encuentran allí un propicio tenor para proyectar a lo alto estampas no solo de Argentina, Brasil o Uruguay, sino de América del Sur y América Latina. 


\section{Referencias bibliográficas}

Bignami, R. (2002). A imagem do Brasil no turismo: Construção, desafios e vantagem competitiva. São Paulo: Aleph.

Campodónico, R., Chalar, L., y Ángelo, G. (2014). Punta del Este: Su centralidad en el imaginario uruguayo. Trabajo presentado en el Congreso Internacional de Investigación Turística, Bogotá.

Campodónico, R., y da Cunha, N. (2009). Mar del Plata y Punta del Este. Entre la permanencia y la renovación. Estudios y Perspectivas en Turismo, 18(5), 606-623.

Campodónico, G., y Zorzi, M. (2019). De lo inhóspito al glamour: Narrativas sobre las transformaciones de Punta del Este, Uruguay, en la mirada de los antiguos residentes. Rosa dos Ventos - Turismo e Hospitalidade, 11(2), 236-252.

Castro, C. (1999). Narrativas e imagens do turismo no Río de Janeiro. En G. Velho (org.), Antropologia urbana: Cultura e sociedade no Brasil e em Portugal (pp. 80-87). Río de Janeiro: Zahar.

Corbin, A. (1989). O território do vazio: A praia e o imaginário ocidental. São Paulo: Companhia das Letras.

da Cunha, N., y Campodónico, R. (2012). Uruguay: Hacia la noción de país turístico. Estudio Histórico 1930-1955. Anuario IEHS, 27, 331-367.

de Azevedo, T. (2016). A praia: Espaço de socialidade. Salvador de Bahía: EDUFBA.

Díaz de Guerra, M. A. (1988). Historia de Maldonado: Tomo II. Maldonado: Intendencia Municipal de Maldonado.

Eltrece. (2010, 3 de marzo). Reloj de arena: Historia del gran balneario argentino. [video]. Recuperado de https://www.eltrecetv.com.ar/videos/telenoche/reloj-dearena-historia-del-gran-balneario-argentino_005254.

Freire-Medeiros, B. (2005). O Río de Janeiro que Hollywood inventou. Río de Janeiro: Zahar.

Gorelik, A. (2002). La ciudad latinoamericana como idea. Punto de Vista, 35(73), 41-48.

Gorelik, A. (2004). Imaginarios urbanos e imaginación urbana: Para un recorrido por los lugares comunes de los estudios culturales urbanos. Bifurcaciones - Revista de Estudios Culturales Urbanos, (1). Recuperado de http://www.bifurcaciones.cl/001/ Gorelik.htm.

Gorelik, A. (2005). A produção da «cidade latino-americana». Tempo Social, 17(1), 111 133.

Gorelik, A. (2007). Las metrópolis latinoamericanas, el arte y la vida: Arte y ciudad en tiempos de globalización. Aisthesis, (41), 36-56.

Guimarães-Lima, V. (2013). 0 turismo como vetor das relações Brasil-Argentina nas décadas de 1920 e 1930. Revista Eletrônica da ANPHLAC, (15), 175-197. 
Hernández, F. M. (2009). Cultura de la playa: Sociabilización, ocio y territorio en los balnearios de la costa atlántica bonaerense, Argentina. Argos, 26(51).

Jajamovich, G., Morales, A. O. C., y López, D. A. (2016). Ciudad latinoamericana: teorías, actores y conflictos. URBANA: Revista Eletrônica do Centro Interdisciplinar de Estudos Sobre a Cidade, 8(3), 1-7. doi:10.20396/urbana.v8i3.8647507.

Mantero, J. C. (1997). Mar del Plata: Devenir urbano y desarrollo turístico. Mar del Plata: Nulan.

Morse, R. (2005). Ciudades «periféricas» como arenas culturales. Bifurcaciones: Revista de Estudios Culturales Urbanos, (3). Recuperado de http://www.bifurcaciones.cl/ 003/bifurcaciones_003_Morse.pdf.

Morse, R. (1957). La ciudad artificial. Revista Estudios Americanos, 13(67-68).

O’Donnell, J. (2013). A invenção de Copacabana. Río de Janeiro: Zahar.

O’Donnell, J. (2014). «Nadie es como nosotros»: Identidades y territorialidades en la invención de Copacabana. Bifurcaciones: Revista de Estudios Culturales Urbanos, (17). Recuperado de http://www.bifurcaciones.cl/2014/06/nadie-es-comonosotros/.

O’Donnell, J., Amaral de Sampaio, L., y Cavalcanti, M. (2020). Entre futuros e ruínas: Os caminhos da Barra Olímpica. Dilemas: Revista de Estudos de Conflito e Controle Social, 13(1), 119-146.

Pastoriza, E. (2011). La conquista de las vacaciones: Historia del turismo en Argentina. Buenos Aires: Edhasa.

Pastoriza, E., y Campodónico, R. (2020). Introducción al tema central n. ${ }^{\circ} 10$ : Historia y Turismo: una perspectiva rioplatense. Claves: Revista de Historia, 6(10). 1-5.

Pastoriza, E., y Pedetta, M. (2009). Lo que el pueblo necesita: Turismo social y Peronismo. Argentina, 1945-1955. Études Caribéennes, 13-14. doi: 10.4000/etudescaribeennes.3767.

Pastoriza, E., y Torre, J. C. (2002). La democratización del bienestar. En J. C. Torre (comp.), Nueva Historia Argentina: Tomo 8 (pp. 257-313). Buenos Aires: Sudamericana.

Pastoriza, E., y Torre, J. C. (2019). Mar del Plata: un sueño de los argentinos. Buenos Aires: Edhasa.

Pastoriza, E., y Zuppa, G. (2004). La conquista de las riberas: Política, cultura, turismo y democratización social. Mar del Plata (1886-1970). Trace, 45, 93-109.

Rama, Á. (1998). La ciudad letrada. Montevideo: Arca.

Rama, Á. (2007). Transculturación narrativa en América Latina. Buenos Aires: El Andariego.

Romero, J. L. (2004). América Latina: As cidades e as ideias. Río de Janeiro: Editora UFRJ. Sarue, B. (2016). Os capitais urbanos do Porto Maravilha. Novos estudos CEBRAP, 35(2), 79-97. 
Simmel, G. (1986). Estudios sobre las formas de socialización. En Sociología: Tomo 2. Madrid: Alianza.

Solomita, M. (2017, 5 de marzo). Kennedy: Los vecinos incómodos de Punta del Este. El País. Recuperado de https://www.elpais.com.uy/que-pasa/kennedy-vecinosincomodos-punta.html.

Trochón, Y. (2017). Punta del Este: El edén oriental. Montevideo: Fin de Siglo.

Urry, J. (2016). Globalizando o olhar do turista. Revista Plural, 23(2), 142-155.

Velho, G. (1999). Os mundos de Copacabana. En G. Velho (ed.), Antropologia urbana. Río de Janeiro: Zahar.

Velho, G. (2004). Individualismo e cultura. Río de Janeiro: Zahar. 